\title{
Dough rheology and the impact of zinc sulfate on the quality of cookies
}

\author{
Muhammad USMAN ${ }^{1}$, Prasanna Jagannath PATIL ${ }^{1}$, Muhammad Faisal MANZOOR ${ }^{2,3}$ (D), \\ Muhammad BILAL ${ }^{3}$, Shabbir AHMED ${ }^{4}$, Mian Anjum MURTAZA ${ }^{5}$, Haroon SHAH ${ }^{1}$, Nida NAWAZ ${ }^{1}$, \\ Sohail AMJAD ${ }^{1}$, Muhammad ABRAR ${ }^{6 *}$
}

\begin{abstract}
Zinc deficiency is a growing issue in developing countries. Moreover, it is a well-known fact that the bakery products have very low zinc content and the further loss of zinc occurs during milling of wheat and under baking of end products, which makes it hard to produce nutritional bakery products. For this purpose, zinc sulfate has been incorporated in wheat flour at $0,32.5$, 65 , and $97.5 \mathrm{mg} / 100 \mathrm{~g}$ to prepare cookies and determine their physicochemical and nutritional properties as well as stability under controlled storage conditions, i.e. temperature $\left(23-25^{\circ} \mathrm{C}\right)$ and relative humidity $(45-55 \%)$. The findings exhibited that the cookies-percentage of fat and protein decreased after the addition of zinc sulfate. The fiber content of cookies was nonsignificantly changed, while the moisture content increased. Moreover, the diameter of cookies significantly increased from $45.65 \pm 1.46 \mathrm{~cm}$ to $45.84 \pm 1.34 \mathrm{~cm}$. The thickness and spread factor of cookies were also effects ranged from 1.49 to $1.54 \mathrm{~cm}$ and $30.63 \pm 2.98$ to $29.76 \pm 1.64$ respectively. The results revealed that zinc sulfate was stable up to 90 days and under normal baking conditions. Based on the sensorial attributes, it was unveiled that the nutritional cookies were prepared by using $65 \mathrm{mg}$ zinc sulfate with (AARI-2011) wheat flour.
\end{abstract}

Keywords: zinc deficiency; dough rheology; fortified cookies; zinc stability.

Practical Application: The cookies have been popular and long shelf life tea time snack. Thus, the finding unveiled that the zinc sulfate can be enhanced the nutritional value of cookies on a large scale.

\section{Introduction}

Micronutrient deficiency is an alarming health issue across the globe caused due to the growing population, uncertainty in energy intake, insufficient public sector, and lack of legislation or inflexible implementation of rules and regulations (Aguayo \& Baker, 2005). Moreover, the differences in an eating pattern that eventually leads to reduce the intake of micronutrients have come out because of a sedentary lifestyle and complicated industrial development (Liu et al., 2019; Visioli \& Hagen, 2007). Zinc deficiency has mainly prevailed owing to insufficient intake or lower absorption of zinc from the diet. It is important to emphasize that many diseases, particularly diarrhea, are major contributors to the losses of zinc. The unavailability of meat and meat products and dependence on plant-based diets appear to be one of the substantial factors to enhance the zinc deficiency in the developing countries, like Pakistan (Akhtar et al., 2011). The evidence-based studies revealed that zinc deficiency is a chronic form of micronutrient deficiency, which hurts one-third population throughout the world (Kennedy et al., 2006; Van den Briel et al., 2007). However, severe zinc deficiency is not common, whereas mild-to-moderate zinc deficiency is prevalent across the globe, particularly in children and lactating mothers (Akhtar et al., 2011).
The national nutrition survey (NNS) of Pakistan exhibited that the zinc deficiency in children under the age of five was found to be $39 \%$ in 2011, whereas it was increased by up to $44 \%$ in 2017. On the other hand, a sufficient amount of zinc in the human body can regulate the metalloenzymes, which play a vital role in the synthesis of protein, gene expression regulation, metabolism of all macromolecules, and improve the immune system (Taylor et al., 2016). Among different types of zinc salts, the zinc sulfate has commonly been used as a fortificants agent in various bakery products due to the "Generally Recognized as Safe" (GRAS) status by the Food and Drug Administration (FDA). Contrarily, the zinc oxide is unacceptable owing to its insolubility in liquid foods and its effect on the organoleptic properties (World Health Organization, 2000). Then, several approaches i.e. supplementation, dietary modification, and food fortification have been introduced to eradicate the risk of zinc deficiencies (Kurek \& Sokolova, 2020; Winger et al., 2008). Nonetheless, from the above strategies, the food fortification remains to be an effective, more practical, cheaper, and long-term strategy in focusing across-the-board populations without the involvement of synthetic drugs (Shubham et al., 2020; Mesa et al., 2019). The scientific-based international 
organizations, such as FDA, WHO, MI, SUSTAIN, and USAID have been vigorously involved to make guidelines for mineral and vitamin fortification of wheat flour according to the consumer's choice (Flour Fortification Initiative, 2008). It is important to point out that the wheat flour is a potential candidate for the fortification of zinc sulfate, as it has widely been consumed (viz. $90 \%$ to $95 \%$ ) as a staple food in the developing countries (Bauernfeind \& Lachance, 1991).

Recently, food fortification has practiced improving the dietary fiber content, antioxidant activity, omega-3, and omega- 6 fatty acid composition of cookies by using apple pomace and peanut seed oil (Bilal et al., 2020; Shahzad et al., 2020; Tagliani et al., 2019; Usman et al., 2020). Moreover, the potato flour, organic grape peel flour, Tinospora cordifolia stem powder, vitamin A, pomegranate peel, microalga arthrosporic platensis, flaxseed flour, Tartary buckwheat malt, sour cherry pomace extract, chenopodium album flour, anthocyanin-rich corn flour, and raspberry, as well as blueberry pomace, were incorporated in cookies to improve the nutritional value (Ahmad et al., 2020; Kaderides et al., 2020; Šarić et al., 2019; Tyagi et al., 2020). Although, the addition of zinc sulfate regarding cookies preparation is less investigated and has been grabbed salient attention owing to the zinc deficiency in developing countries. Notwithstanding, the incorporation of micronutrients could jeopardize the chemical composition of wheat flour and wheat flour-based products (Akhtar et al., 2011). It can be compromised in a view of considerable health and economic benefits of micronutrient fortification in the wheat flour (Akhtar et al., 2009). However, choosing the appropriate type of zinc salt, following the recommended dietary allowance (RDA) at an individual level, and utilizing effective processing technologies can improve the nutritional value of final products.

The reported RDA of zinc for adults, infants, and children is about 16,5 , and $10 \mathrm{mg} /$ day, respectively. Though, in consideration of men and lactating mothers, it has found about 15 and $16 \mathrm{mg} /$ day respectively with normal body mass index (Khalid et al., 2014). Hence, for the development of nutritious cookies, it is essential to understand the fate and stability of zinc sulfate under CSC and after baking. Thus, the present study is planned to conceal the appropriate level of zinc sulfate for cookies production with elegant physicochemical and nutritional attributes.

\section{Materials and methods}

\subsection{Materials}

The AARI-2011 is a type of hard wheat and has obtained from Wheat Research Institute, Ayub Agriculture Research Institute (AARI) Pakistan. Moreover, the zinc sulfate was purchased from Sigma-Aldrich Pvt. Ltd. (Castle Hill, Australia). All other chemicals utilized in this research work were acquired from MerckMillipore Pvt. Ltd. (Darmstadt, Germany). The ingredients, such as vegetable shortening, table salt, sucrose, sodium bicarbonate were purchased from the local market in Faisalabad, Pakistan. The present research was performed in the Hi-Tech laboratories of AARI Faisalabad, Pakistan.

\subsection{Primary treatment and physical tests of AARI-2011 wheat}

The ARRI-2011-wheat grains were prepared to get rid of weeds, damaged grains, seeds of other crops, dust, metals, etc. The test weight and thousand kernel weight were measured according to the methods presented in American Association of Cereal Chemists (2000). Moreover, the AARI-2011-wheat grains were tempered at room temperature by using a $15 \%$ moisture level for $24 \mathrm{~h}$ in a closed container owing to equilibrate the moisture content. Furthermore, the tempered wheat was milled by using Quadrumate Senior Mill (C.W. Brabender, Duisburg, Germany) as stated by American Association of Cereal Chemists (2000) method no. 26-10A. The flours i.e., reduction flour and break flour were mixed (on a dry basis w/w) with an equal ratio to prepare straight grade flour (SGF). The SDS-sedimentation value and Pelshenke value were analyzed as claimed by American Association of Cereal Chemists (2000) method no 56-50 and 56-61-3 respectively. Dry and wet gluten contents were determined by applying the method 38-10 (Association of Official Analytical Chemists, 2005). The falling number is a significant value to evaluate the $\alpha$-amylase activity of wheat flour and was determined by using a machine Perten falling number 1700, (Perten Instruments, Inc., Springfield, IL) according to the approved method no. 56-81 (American Association of Cereal Chemists, 2000).

\subsection{Chemical analysis of wheat flour}

The chemical analyses, i.e. crude fiber, crude fat, moisture, ash, and NFE (Nitrogen free extract) of AARI-2011-SGF were measured as reported in the methods of American Association of Cereal Chemists (2000). Moreover, a 3-5 g sample was kept in a pre-weighed china dish and place in a hot air oven at $100 \pm$ $5{ }^{\circ} \mathrm{C}$ for $24 \mathrm{~h}$. The moisture content was measured by loss on drying from the sample. Then, a 5-10 g moisture-free sample was prepared and washed 5-6 times by using petroleum ether in the Soxhlet apparatus. The loss in weight from the sample was accounted for as a crude fat percentage. In the case of fiber determination, $5 \mathrm{~g}$ moisture-free and a fat-free sample were digested by using $1.25 \% \mathrm{H}_{2} \mathrm{SO}_{4}$ for 30 mint. Furthermore, the obtained-supernatant was digested in $1.25 \% \mathrm{NaOH}$ solution for 30 mint. Subsequently, the supernatant was weighed in a crucible and placed in the muffle furnace at $550^{\circ} \mathrm{C}$ for $5 \mathrm{~h}$. Finally, the weight loss was noted as crude fiber content. For the determination of ash percentage, a 1-3 g sample was burned on direct flame and place in a muffle furnace at $550^{\circ} \mathrm{C}$ for $5-6 \mathrm{~h}$, as a result, the weight of residue was noted as ash content. For crude protein determination, a 1-3 g sample was digested through $30 \mathrm{~mL} \mathrm{H}_{2} \mathrm{SO}_{4}$ for 3-4 $\mathrm{h}$ by using a combustion analyzer (Combustion Analyzer CN 628, LECO Corporation, St. Joseph, MI) according to the method no. 46-30 (American Association of Cereal Chemists, 2000). The digested-sample volume was adjusted to $200 \mathrm{~mL}$ by using purified water and $10 \mathrm{~mL}$ from this was used in the distillation unit to expel ammonia gas, which was collected in $10 \mathrm{~mL}$ boric acid (4\%) solution. Moreover, this ammonium borate was titrated using $0.1 \mathrm{~N} \mathrm{H}_{2} \mathrm{SO}_{4}$ till light pink color appeared. Finally, ammonia percentage was determined by a formula and multiplied by 6.25 factor to calculate protein 
content in the sample. NFE was calculated by subtracting the percentage of all components from 100 .

\subsection{Rheological characteristics}

The rheological attributes of AARI-2011-SGF, for instance, DDT (dough development time), WA (water absorption), DT (departure time), MTI (mixing tolerance index), DS (dough stability), AT (arrival time), and DS (dough softening) were analyzed by using Brabender Farinograph instrument (C.W. Brabender, Duisburg, Germany) as stated in the method no. 54-21 (American Association of Cereal Chemists, 2000).

\subsection{Wheat flour preparation for zinc sulfate cookies}

The blended flour was prepared by mixing zinc sulfate at 0 , $32.5,65$, and $97.5 \mathrm{mg} / 100 \mathrm{~g}$ with ARRI-11-SGF in a dry mixer for 10 min (JHX 4, DM New Century, Zhejiang, China) and used for further analysis.

\subsection{Product development}

From the above-mentioned treatment plan, the cookies were produced as explained by Usman et al. (2020) with some modifications. The zinc sulfate-free-cookies recipe was based on flour weight was: AARI-2011-SGF $500 \mathrm{~g}$, sodium bicarbonate $8 \mathrm{~g}$, table sugar $250 \mathrm{~g}$, milk $32 \mathrm{~mL}$, sodium chloride $4.1 \mathrm{~g}$, vegetable shortening $250 \mathrm{~g}$, and water $30 \mathrm{~cm}^{3}$ precisely. Two drops of vanilla flavor and two eggs were also incorporated in the formula of cookies to enhance palatability. Initially, creaming was prepared by incorporation of shortening in a Hobart mixer (Model N-50, Hobart Mfg. Co. Troy, Ohio, USA) for 30 mint. Egg and milk were incorporated to obtain a homogenous mass. Then, a blended flour sample and baking powder were added with edible table salt. Subsequently, the final cookies-dough was rolled twenty times, cut into a round shape, and baked at $175 \pm 5^{\circ} \mathrm{C}$ for $25 \mathrm{mint}$ by using an electric oven. The zinc sulfate cookies were cooled, sealed [bioriented polypropylene (BOPP)], and stored at room temperature for further analysis.

\subsection{Chemical composition of cookies}

The cookies were arranged for chemical analysis as mentioned in section chemical analysis of AARI-2011-SGF.

\subsection{Physical properties of cookies}

The physical analyses of cookies, such as thickness, diameter, and spread factor were determined as claimed by Kaur et al. (2013). Consequently, six cookies were chosen and designed over each other, and the thickness was measured by using Vernier caliper in $\mathrm{cm}$. Likewise, six cookies were placed edge to edge, and the total length was determined in $\mathrm{cm}$ through the ruler. Subsequently, the diameter was obtained by dividing the value by six. It is important to mention that the cookies were rotated by an angle of $90^{\circ}$ for identical readings. Moreover, the value of the spread factor was acquired by dividing the diameter over thickness.

\subsection{Stability analysis of zinc sulfate}

The stability of zinc fortificants was determined for fresh and stored cookies up to 90 days with the standard wavelength and absorbance for zinc sulfate, according to the method reported by Akhtar et al. (2011). Purposely, a $0.5 \mathrm{~g}$ sample was taken in a $100 \mathrm{~mL}$ flask and digested by adding $10 \mathrm{~mL}$ boric acid at $60-70{ }^{\circ} \mathrm{C}$ for $20 \mathrm{~min}$. Moreover, the same sample was digested using $5 \mathrm{~mL}$ of $\mathrm{HClO}_{4}$ at $60-70{ }^{\circ} \mathrm{C}$ for $20 \mathrm{~min}$. Afterward, the temperature was increased up to $195^{\circ} \mathrm{C}$ until the sample exhibited transparency or reduced to 1-2 $\mathrm{mL}$. Furthermore, the digested sample was mixed in deionized water in the volumetric flask. The final sample was subjected to run on Atomic Absorption Spectrophotometer (Perkin Elmer-100), which was adjusted to provide optimum conditions.

\subsection{Sensory evaluation}

The acceptability and quality of cookies as well as the effect of zinc sulfate on cookies were estimated by evaluating the scores of color, flavor, texture, taste, crispiness, mouth feel, and overall acceptability. Sample with various zinc sulfate levels was subjected to a panel of 40 members (20 females and 20 males), which were aged between 25 to 50 years, non-celiac, and nonsmokers nominated from AARI Faisalabad, Pakistan. The panelists were instructed to assess the aforementioned attributes and to score each parameter by using a nine-point hedonic scale with 1 (poor organoleptic cookies), 5 (average cookies), and 9 (highly palatable cookies) as mentioned by Meilgaard et al. (2007) with some modifications. The sensory characteristics were performed in the laboratory at $22{ }^{\circ} \mathrm{C}$ with clean sensory cabins containing freshwater.

\subsection{Statistical analysis}

The findings have evaluated using ANOVA (analysis of variance). The experiments were arranged in duplicate and received data were analyzed through the statistical software Graphics Plus for Windows, Version 3.1 (Statsoft -Inc., USA). The average values of graphs and tables were calculated using MS Excel 2013. Means were compared through Duncan's multiple range test.

\section{Results}

\subsection{Physico-chemical properties of AARI-2011- wheat flour}

The average values of test weight and thousand kernel weight of AARI-2011-wheat grains were about $41.91 \mathrm{~g}$ and $76.15 \mathrm{~kg}$. $\mathrm{hL}^{-1}$ respectively and are presented in Table 1 . These results were in agreement with the outcomes of Khan (2016), who reported the thousand kernel weight (25.98 g to $40 \mathrm{~g}$ ) and test weight (66.47 to $\left.76.90 \mathrm{~kg} . \mathrm{hL}^{-1}\right)$. Pasha et al. (2013) have also elucidated similar results regarding thousand kernel weight and test weight, reaching $41 \mathrm{~g}$ and $79 \mathrm{~kg}$. $\mathrm{hL}^{-1}$ respectively for AARI-2011 wheat grain. It was obvious from the result that AARI-2011-SGF possessed a considerable amount of dry and wet gluten, i.e. $8.11 \%$ and $22.97 \%$ respectively. Anjum \& Walker (2000) have also revealed the dry and wet gluten, which varied from 8.88 to $10.09 \%$ and 27.60 to $35.15 \%$ respectively. The variation in these findings 
Table 1. Physico-chemical Analysis of AARI-2011 Wheat and AARI-2011-SGF.

\begin{tabular}{|c|c|}
\hline Parameters & Mean Values \\
\hline Thousand kernel weight (g) & $40.39 \pm 0.45$ \\
\hline Test weight $\left(\mathrm{kg} \cdot \mathrm{hL}^{-1}\right)$ & $73.05 \pm 0.65$ \\
\hline Falling Number (sec.) & $477.00 \pm 5.15$ \\
\hline Wet gluten (\%) & $22.97 \pm 0.66$ \\
\hline Dry Gluten (\%) & $8.11 \pm 0.03$ \\
\hline SDS-Sedimentation Value (mL) & $25.02 \pm 0.09$ \\
\hline Pelshenke Value (min.) & $191.08 \pm 1.85$ \\
\hline \multicolumn{2}{|c|}{$\begin{array}{l}\text { AARI = Ayub Agricultural Research Institute-2011; SGF = Straight Grade Flour; } \\
\%=\text { Percentage; } g=\mathrm{Gram} ; \mathrm{kg} . \mathrm{hL}^{-1}=\text { Bulk density of wheat grain; } \mathrm{sec}=\text { Time in } \\
\text { seconds for a stirrer to fall through a hot slurry of ground wheat; min. = Time for the } \\
\text { estimation of gluten strength through gas production and retention capacity of the wheat } \\
\text { carbohydrate/protein complex. }\end{array}$} \\
\hline
\end{tabular}

Table 2. Chemical Analysis AARI-2011-SGF.

\begin{tabular}{cc}
\hline Parameters & Mean Values \\
\hline Moisture \% & $13.05 \pm 0.03$ \\
Fat \% & $1.06 \pm 0.009$ \\
Fiber \% & $0.29 \pm 0.006$ \\
Protein \% & $11.60 \pm 0.20$ \\
Ash \% & $0.60 \pm 0.001$ \\
NFE \% & $74.17 \pm 0.67$
\end{tabular}

$\%=$ Percentage; AARI = Ayub Agricultural Research Institute-2011; SGF = Straight Grade Flour.

Table 3. Rheological Attributes of AARI-2011-SGF.

\begin{tabular}{cc}
\hline Parameters & Mean Values \\
\hline WA (\%) & $56.33 \pm 0.04$ \\
DS (BU) & $129.06 \pm 1.33$ \\
DDT (min.) & $5.12 \pm 0.97$ \\
DS (min.) & $16.10 \pm 0.17$ \\
MIT (BU) & $52.21 \pm 0.44$ \\
AT (min.) & $0.89 \pm 0.02$ \\
DT (min.) & $20.02 \pm 0.11$
\end{tabular}

WA = Water Absorption; DS = Dough Softening; DDT = Dough Development Time; DS = Dough Stability; MIT = Mixing Tolerance Index AT = Arrival Time; DT = Departure Time.

is may be due to the difference in varieties and experimental conditions. As expected, the falling number of AARI-2011SGF has depicted low amylase activity and found to be about $477.00 \mathrm{~min}$. The present findings were consistent with the results of Pasha et al. (2007). Moreover, the values of Pelshenke and SDS-sedimentation of AARI-2011-SGF have reached $25.02 \mathrm{~mL}$ and $191.08 \mathrm{~min}$ respectively. Panjagari et al. (2015) have unveiled the same results concerning SDS-sedimentation. As shown in Table 2, the AARI-2011-SGF comprised 13.5\% moisture, 11.60\% protein, and $72.97 \%$ carbohydrate. Although, it is a well-known fact that, the Pakistani wheat varieties, including AARI-2011, exhibit insignificant fiber and zinc content, i.e. $0.26 \%$ and $29.0 \mathrm{mg} \mathrm{kg}^{1}$ respectively. Thus, it is a judicious approach to fortify the cookies with zinc sulfate and improve the RDA of zinc in pregnant women as well as adults and children.

\subsection{Rheological properties}

Rheological characteristics of wheat flour are cutting edge and are essentially evaluated to produce elegant cereal-based products. Moreover, the rheological qualities of dough transform significantly under heating and during mixing, consequently, the gluten proteins and starch granules experience structural modifications to form three-dimensional matrices using proteincarbohydrate and protein-protein interactions. Therefore, the evaluation of the rheological properties of dough is effective in revealing the quality of end products. As shown in Table 3 , the WA of AARI-2011-SGF has found to be $56.33 \%$, whereas, the DS and MTI reached $129.06 \mathrm{BU}$ and $52.21 \mathrm{BU}$ respectively. As expected, the AT, DT, DDT, and DS of AARI-2011-SGF were appeared to be $0.89,20.02,5.12$, and 16.10 min respectively. These findings were consistent with the outcomes of Safdar et al. (2012).

\subsection{Chemical analysis of cookies}

It is important to point out that the addition of zinc sulfate is may be obnoxious for wheat-based food products regarding chemical composition and sensorial characteristics (Niemesh, 2015). However, Akhtar et al. (2011) unveiled that the addition of soluble zinc salt, for instance, zinc sulfate is a prudent approach to control zinc deficiency in humans. Moreover, it does not affect the threshold chemical values of cereal-based products. Besides, this study also revealed that the zinc sulfate, i.e. of 32.5 , 65 , and $97.5 \mathrm{mg} / 100 \mathrm{~g}$ concentration, had no major effect on the chemical composition of cookies, which are depicted in Figure 1A. Contrarily, the average moisture content of cookies was increased as the storage time increased, which ranged from $2.46 \%$ to $2.79 \%$ at 0 days to 90 days respectively (Figure 1B). It was obvious that the highest moisture percentage (2.49\%) was found in $\mathrm{T}_{3}(97.5 \mathrm{mg} / 100 \mathrm{~g})$ zinc sulfate fortified cookies. On the other hand, the mean value of fat (i.e. from 22.89 to $22.66 \%$ ) and protein (i.e. from 6.43 to $6.20 \%$ ) showed a decreasing trend during storage due to an upsurge in moisture percentage. Moreover, the average lowest values of protein (6.23\%) and fat (22.70\%) were observed in $\mathrm{T}_{3}$. However, the different levels of zinc sulfate and storage time did not affect ash content and crude fiber of cookies.

\subsection{Physical analysis of cookies}

The average results regarding the diameter of cookies were slightly changed using different levels of zinc sulfate and storage interval. It was observed that the $\mathrm{T}_{3}$ exhibited the highest mean value regarding diameter $(4.84 \mathrm{~cm})$ and thickness $(0.52 \mathrm{~cm})$ of cookies as mentioned in Table 4. In the case of a storage study, the diameter of cookies was ranged from 4.78 to $4.65 \mathrm{~cm}$ for 0 days and up to 3 months respectively. On the contrary, the storage conditions did not affect the thickness of cookies. However, the spread factor of cookies was significantly affected $(p<0.05)$ through the addition of zinc sulfate. Furthermore, the $\mathrm{T}_{0}$ (control treatment) showed the maximum value of the spread factor, i.e. 93.84, and it was different from the above-mentioned physical parameters of cookies. In a view of storage time, the spread factor of cookies was found to be 93.73 and 89.96 for 0 days and 90 days respectively. 


\subsection{Sensory analysis of cookies}

The results concerning the sensorial properties of cookies, for instance, flavor, taste crispiness, color, texture, and overall acceptability have depicted that the various levels of zinc sulfate and storage time significantly altered the sensory attributes, which shown in Figure 2A, B. As presented in Figure 2A, the highest average color value was observed in $\mathrm{T}_{2}(65 \mathrm{mg} / 100 \mathrm{~g})$ reaching $7.22 \mathrm{mg} / 100 \mathrm{~g}$. Likewise, the flavor of cookies was also evidently alleviated during storage (i.e. 0 days to 90 days) from 7.92 to 6.12 respectively. Similarly, from the value of color, the $\mathrm{T}_{2}$ had the highest flavor score of about 7.14. The mean value of
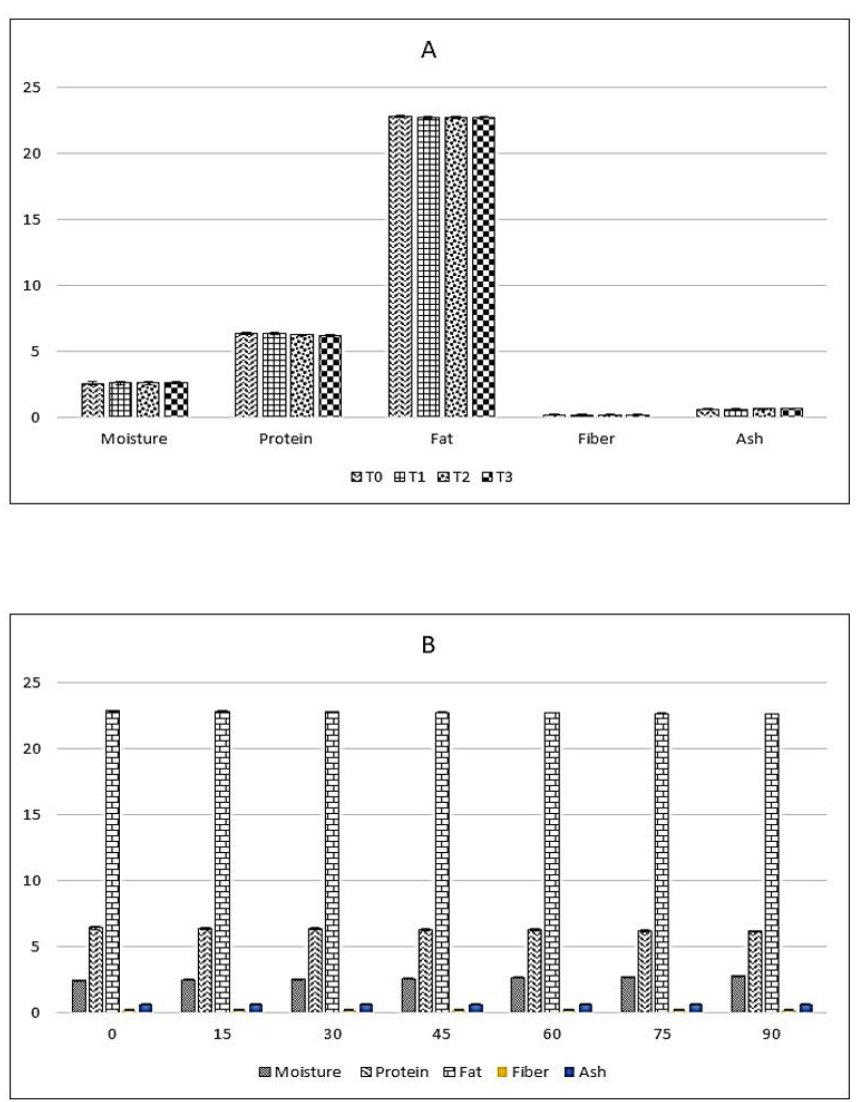

Figure 1. (A) Effect of different levels of zinc sulphate on the proximate composition of cookies; (B) Effect of storage time on the proximate composition of zinc sulphate cookies. taste before storage (8.00) and after storage (5.85) of cookies had shown a declining trend. The maximum average score for taste (7.01) was found in $\mathrm{T}_{2}$. In consideration of texture and crispiness of cookies, the highest value was observed in $\mathrm{T}_{1}(32.5 \mathrm{mg} / 100 \mathrm{~g})$, i.e. 7.22 for both sensorial attributes. On the contrary, the storage time has noticeably changed the values for each parameter ranged from 8.20 to 6.22 and 8.02 to 6.25 respectively. It was noted that the mean value of fresh cookies color scored about 7.97, while it was decreased and seemed to be 6.30 after 90 days. The mean value of $\mathrm{T}_{2}$ elucidated the excellent score (7.76) concerning the overall acceptability of cookies. Although, the storage study revealed that the overall acceptability was strikingly reduced from 7.85 to 5.95 (Figure 2B).

\subsection{Stability of zinc sulfate}

The current study revealed that the zinc sulfate showed elegant stability during storage and baking. As described in Figure 3A, the different levels of zinc sulfate prominently changed the value of zinc from 1.31 to $37.80 \mathrm{mg} / 100 \mathrm{~g}$ for $\mathrm{T}_{0}$ and $\mathrm{T}_{3}$ respectively. However, the heating process has shown some loss of zinc sulfate $(1.31 \%)$. The results suggested that the zinc sulfate is stable during baking of cookies at ordinary temperatures (Figure 3C). Then, the stability of zinc sulfate was also estimated during storage. The results revealed that the zinc sulfate was decreased during storage from 20.01 to $17.50 \mathrm{mg} / 100 \mathrm{~g}$ (Figure 3B). When summarized the loss of zinc sulfate during storage and under baking of cookies, it was found approximately about 3.25\% to $4.30 \%$. From the above findings, it can be concluded that the zinc sulfate exhibit exquisite stability under storage and baking conditions of this study. It is important to emphasize that the appropriate baking condition, encapsulation strategy, and quality of fortificants could further improve the stability of zinc sulfate.

\section{Discussion}

Differences in thousand kernel weight and chemical composition of wheat flour are may be owing to the variation in genetic order, genotype, area of production, soil nutrients, and environmental conditions. Moreover, the moisture content of cookies has augmented with an increase in the zinc sulfate and storage time which is maybe due to the moisture present in the air that entered the packaging material (Butt et al., 2004; Sharif et al., 2005). On the contrary, the fat and protein percentage of cookies was decreased owing to the escalation of moisture content in cookies during storage, which can

Table 4. Effect of different levels of zinc content and storage time on physical analysis of cookies.

\begin{tabular}{cccccccc}
\hline Treatments & Diameter $(\mathrm{mm})$ & Thickness $(\mathrm{mm})$ & Spread Factor & Storage Days & Diameter $(\mathrm{mm})$ & Thickness $(\mathrm{mm})$ & Spread Factor \\
\hline $\mathrm{T}_{\mathbf{0}}$ & $45.65 \pm 1.46^{\mathrm{d}}$ & $1.49 \pm 0.015^{\mathrm{c}}$ & $30.63 \pm 2.98$ & $\mathbf{0}$ & $45.74 \pm 1.65$ & $1.51 \pm 0.02$ & $30.29 \pm 3.10$ \\
$\mathrm{~T}_{1}$ & $45.67 \pm 1.49^{\mathrm{c}}$ & $1.51 \pm 0.018^{\mathrm{b}}$ & $30.24 \pm 3.57$ & $\mathbf{1 5}$ & $45.76 \pm 1.71$ & $1.51 \pm 0.01$ & $30.30 \pm 3.45$ \\
$\mathrm{~T}_{2}$ & $45.69 \pm 1.06^{\mathrm{b}}$ & $1.52 \pm 0.01^{\mathrm{ab}}$ & $30.05 \pm 2.50$ & $\mathbf{3 0}$ & $45.72 \pm 1.84$ & $1.51 \pm 0.02$ & $30.27 \pm 1.63$ \\
$\mathrm{~T}_{3}$ & $45.84 \pm 1.34^{\mathrm{a}}$ & $1.54 \pm 0.008^{\mathrm{a}}$ & $29.76 \pm 1.64$ & $\mathbf{4 5}$ & $45.71 \pm 1.81$ & $1.51 \pm 0.01$ & $30.27 \pm 2.84$ \\
& & & & $\mathbf{6 0}$ & $45.69 \pm 1.84$ & $1.51 \pm 0.01$ & $30.25 \pm 2.98$ \\
& & & & $\mathbf{7 5}$ & $45.67 \pm 1.84$ & $1.51 \pm 0.01$ & $30.24 \pm 2.73$ \\
& & & & $\mathbf{9 0}$ & $45.65 \pm 1.83$ & $1.51 \pm 0.01$ & $30.23 \pm 2.97$ \\
\hline
\end{tabular}

$\mathrm{T}_{0}=$ Control; $\mathrm{T}_{1}=32.5 \mathrm{mg} / 100 \mathrm{~g}$ zinc sulphate; $\mathrm{T}_{2}=65 \mathrm{mg} / 100 \mathrm{~g}$ zinc sulphate; $\mathrm{T}_{3}=97.5 \mathrm{mg} / 100$. Values haring different letters are significant $(\mathrm{P}<0.01)$ from each other while values without lettering indicates non-significant difference from each other. 

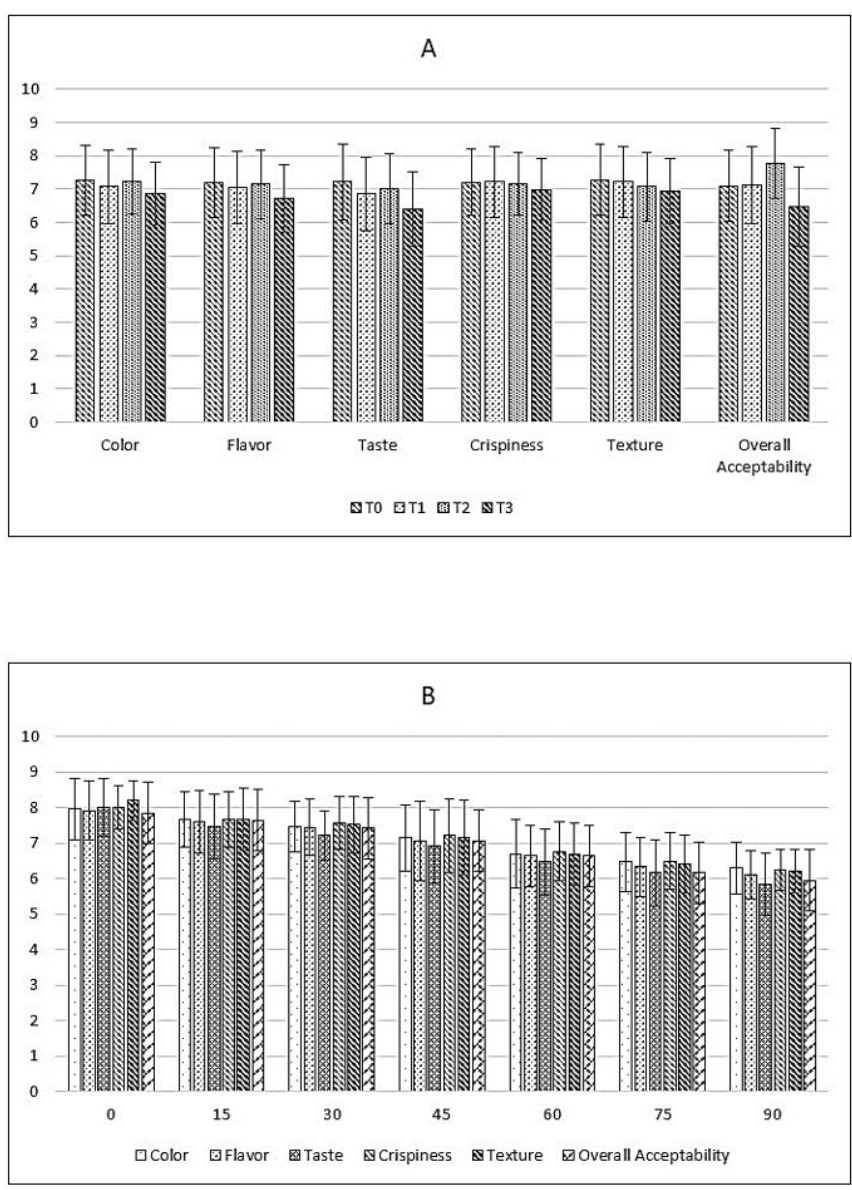

Figure 2. (A) Effect of different levels of zinc sulphate on sensorial attributes of cookies; (B) Effect of storage time on sensorial attributes of zinc sulphate cookies. accelerate the proteolysis and oxidation of fatty acids respectively (Akhtar \& Anjum, 2007; Butt et al., 2007). Furthermore, the fiber content of cookies did not change during storage and by different levels of zinc sulfate, which is indicating that the zinc sulfate could not interact with fibrous material. (Akhtar et al., 2008; Pasha et al., 2002). In the case of physical analysis of cookies, the parameters such as spread factor diameter and thickness are essential for both consumers' and the bakers' point of view. Taylor et al. (2008) and Sharif et al. (2005) have reported that the decline in the diameter and thickness of cookies was may be due to the reduction in gluten strength and starch network as an increase in zinc sulfate. Moreover, moisture content of the flour, the particle size of flour, and the type of shortening are also significant factors for alteration in the physical properties of cookies.

The cookies were analyzed by using the 9-point hedonic scale to ascertain the appropriate levels of zinc sulfate for cookies preparation. Average results regarding sensory properties unveiled that the storage time can be affected by all sensory attributes significantly. The results regarding overall acceptability, texture, color, and crispiness of cookies were decreased, which is maybe owing to the migration and intake of moisture during storage (Manley, 2011; McWatters et al., 2003). Also, the decrease in the flavor of cookies was observed, which was due to the amount of moisture percentage augmented during storage, that proliferated the oxidation of fat, and as a result, flavor deterioration occurred (Akhtar \& Anjum, 2007). Besides, the decline in taste scores as an increase in storage time was feasible due to the lipolysis reaction occurred in the presence of high moisture content (Akhtar \& Anjum, 2007; Butt et al., 2007). Based on the chemical, compositional, physical, and sensorial analysis of cookies, it can be concluded that the most suitable cookies have been prepared using $65 \mathrm{mg} / 100 \mathrm{~g}$ zinc sulfate.
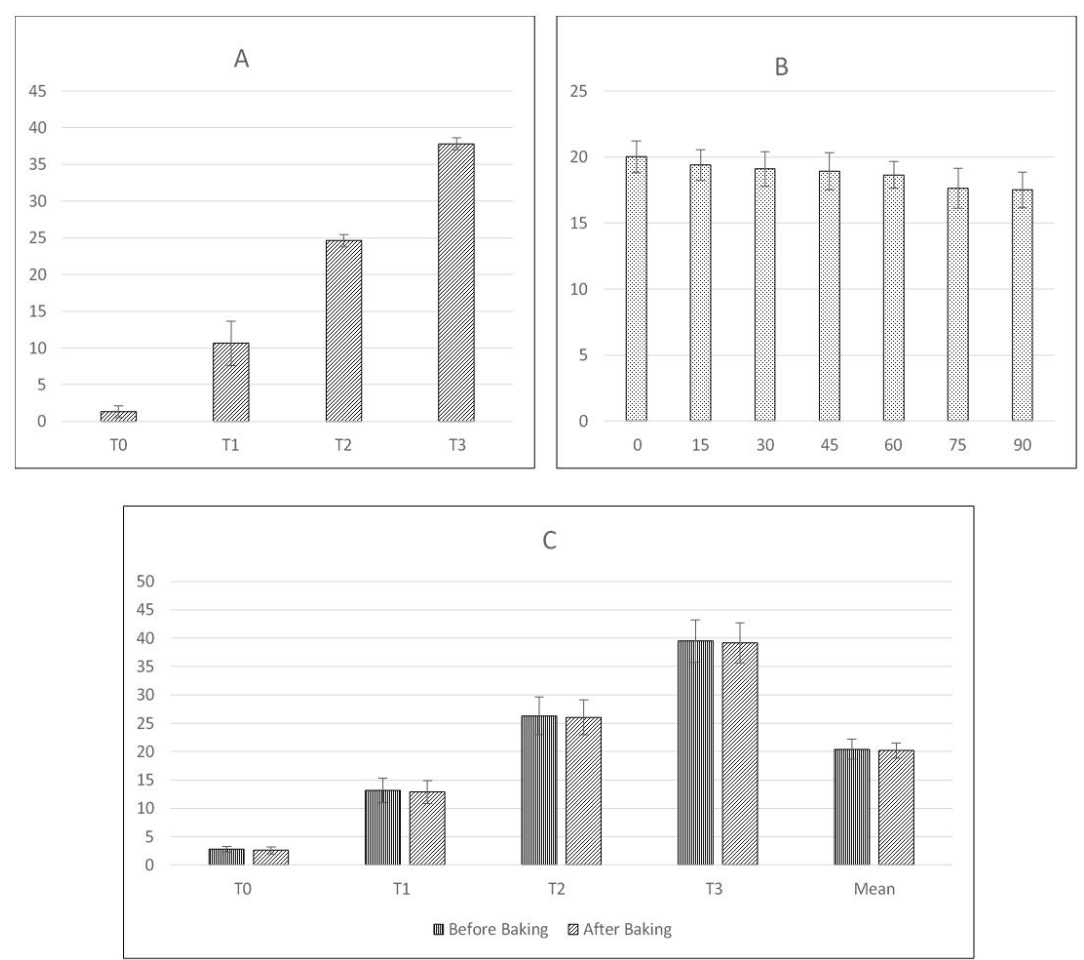

Figure 3. (A) Effect of different levels of zinc sulphate on cookies; (B) Stability of zinc sulphate cookies (B) during storage; and (C) under baking. 


\section{Conclusion}

Food fortification through zinc sulfate in bakery products remains to be a promising approach to reduce zinc deficiency in the developing country. The findings concerning zinc sulfate stability revealed that this is a practical strategy to produce a good quality product. Furthermore, the appropriate storage and processing conditions, such as mixing of cookies ingredients, baking, food safety, packaging material, particular temperature, and relative humidity can minimize the losses of zinc sulfate.

\section{Acknowledgements}

This work was supported by the Cereal Laboratory and Post-Harvest Research Center of Ayub Agriculture Research Institute Faisalabad, Pakistan.

\section{References}

Aguayo, V. M., \& Baker, S. K. J. F. (2005). Vitamin A deficiency and child survival in sub-Saharan Africa: a reappraisal of challenges and opportunities. Food and Nutrition Bulletin, 26(4), 348-355. http://dx.doi.org/10.1177/156482650502600404. PMid:16465981.

Ahmad, N., Manzoor, M. F., Shabbir, U., Ahmed, S., Ismail, T., Saeed, F., Nisa, M., Anjum, F. M., \& Hussain, S. (2020). Health lipid indices and physicochemical properties of dual fortified yogurt with extruded flaxseed omega fatty acids and fibers for hypercholesterolemic subjects. Food Science \& Nutrition, 8(1), 273-280. http://dx.doi. org/10.1002/fsn3.1302. PMid:31993153.

Akhtar, S., \& Anjum, F. M. J. (2007). Sensory characteristics of whole wheat mineral fortified chapattis. Pakistan Journal of Nutrition, 6(6), 681-686. http://dx.doi.org/10.3923/pjn.2007.681.686.

Akhtar, S., Anjum, F. M., \& Anjum, M. A. (2011). Micronutrient fortification of wheat flour: recent development and strategies. J Food Research International, 44(3), 652-659. http://dx.doi.org/10.1016/j. foodres.2010.12.033.

Akhtar, S., Anjum, F., Rehman, S. U., \& Sheikh, M. A. (2009). Effect of mineral fortification on rheological properties of whole wheat flour. Journal of Texture Studies, 40(1), 51-65. http://dx.doi.org/10.1111/ j.1745-4603.2008.00169.x.

Akhtar, S., Anjum, F., Rehman, S.-U., Sheikh, M. A., \& Farzana, K. (2008). Effect of fortification on physico-chemical and microbiological stability of whole wheat flour. Food Chemistry, 110(1), 113-119. http://dx.doi.org/10.1016/j.foodchem.2008.01.065. PMid:26050173.

American Association of Cereal Chemists - AACC. (2000). Approved methods of the American Association of Cereal Chemists (Vol. 54, p. 21). St. Paul.

Association of Official Analytical Chemists - AOAC. (2005). Official methods of analysis of AOAC International. AOAC International.

Anjum, F., \& Walker, C. E. (2000). Grain, flour and bread-making properties of eight Pakistani hard white spring wheat cultivars grown at three different locations for 2 years. International Journal of Food Science \& Technology, 35(4), 407-416. http://dx.doi.org/10.1046/j.13652621.2000.00400.x.

Bauernfeind, J. C., \& Lachance, P. A. (1991). Nutrient additions to food: nutritional, technological and regulatory aspects. Trumbull: Food \& Nutrition Press

Bilal, M., Shabbir, M. A., Xiaobo, Z., Arslan, M., Usman, M., Azam, M., Aadil, R. M., \& Ahmad, N. (2020). Characterization of peanut seed oil of selected varieties and its application in the cereal-based product. Journal of Food Science and Technology, 57(11), 4044-4053. http://dx.doi.org/10.1007/s13197-020-04437-y. PMid:33071326.

Butt, M. S., Arshad, M. U., Alam, M. S., \& Nadeem, M. T. J. (2007). Bioavailability and storage stability of vitamin A fortificant (retinyl acetate) in fortified cookies. Food Research International, 40(10), 1212-1219. http://dx.doi.org/10.1016/j.foodres.2007.07.002.

Butt, M., Sharif, K., Huma, N., Mukhtar, T., \& Rasool, J. J. N. (2004). Storage studies of red palm oil fortified cookies. Nutrition \& Food Science, 34(6), 272-276. http://dx.doi.org/10.1108/00346650410568345.

Flour Fortification Initiative. (2008). Second technical workshop on wheat flour fortification: practical recommendations for National Application Summary Report. Georgia.

Kaderides, K., Mourtzinos, I., \& Goula, A. M. J. F. (2020). Stability of pomegranate peel polyphenols encapsulated in orange juice industry by-product and their incorporation in cookies. Food Chemistry, 310, 125849. http://dx.doi.org/10.1016/j.foodchem.2019.125849. PMid:31753686.

Kaur, A., Singh, N., Ahlawat, A. K., Kaur, S., Singh, A. M., Chauhan, H., \& Singh, G. P. (2013). Diversity in grain, flour, dough and gluten properties amongst Indian wheat cultivars varying in high molecular weight subunits (HMW-GS). Food Research International, 53(1), 63-72. http://dx.doi.org/10.1016/j.foodres.2013.03.009.

Kennedy, G., Nantel, G., Brouwer, I. D., \& Kok, F. J. J. (2006). Does living in an urban environment confer advantages for childhood nutritional status? Analysis of disparities in nutritional status by wealth and residence in Angola, Central African Republic and Senegal. Public Health Nutrition, 9(2), 187-193. http://dx.doi.org/10.1079/ PHN2005835. PMid:16571172.

Khalid, N., Ahmed, A., Bhatti, M. S., Randhawa, M. A., Ahmad, A., \& Rafaqat, R. (2014). A question mark on zinc deficiency in 185 million people in Pakistan-possible way out. Critical Reviews in Food Science and Nutrition, 54(9), 1222-1240. http://dx.doi.org/10 .1080/10408398.2011.630541. PMid:24499152.

Khan, K. (2016). Wheat: chemistry and technology. New York: Elsevier.

Kurek, M. A., \& Sokolova, N. (2020). Optimization of bread quality with quinoa flour of different particle size and degree of wheat flour replacement. Food Science and Technology, 40(2), 307-314. http:// dx.doi.org/10.1590/fst.38318.

Liu, Y., Ma, X.-Y., Liu, L.-N., Xie, Y.-P., Ke, Y.-J., Cai, Z.-J., \& Wu, G.-J. (2019). Ultrasonic-assisted extraction and functional properties of wampee seed protein. Food Science and Technology, 39(Suppl. 1), 324-331. http://dx.doi.org/10.1590/fst.03918.

Manley, D. (2011). Manley's technology of biscuits, crackers and cookies. Cambridge: Elsevier. http://dx.doi.org/10.1533/9780857093646.

McWatters, K. H., Ouedraogo, J. B., Resurreccion, A. V., Hung, Y. C., \& Phillips, R. D. (2003). Physical and sensory characteristics of sugar cookies containing mixtures of wheat, fonio (Digitaria exilis) and cowpea (Vigna unguiculata) flours. International Journal of Food Science \& Technology, 38(4), 403-410. http://dx.doi.org/10.1046/ j.1365-2621.2003.00716.x.

Meilgaard, M., Civille, G., \& Carr, B. (2007). Overall difference tests: does a sensory difference exist between samples (pp. 63-104). Boca Raton: CRC Press.

Mesa, E., Manjarres-Pinzon, K., \& Rodriguez-Sandoval, E. (2019). Gluten-free cheese bread from frozen dough: effect of modified cassava starch. Food Science and Technology, 39(Suppl. 2), 654-661. http://dx.doi.org/10.1590/fst.30118.

Niemesh, G. T. J. (2015). Ironing out deficiencies: evidence from the united states on the economic effects of iron deficiency. The Journal 
of Human Resources, 50(4), 910-958. http://dx.doi.org/10.3368/ jhr.50.4.910.

Panjagari, N. R., Singh, A. K., Ganguly, S., \& Indumati, K. P. (2015). Beta-glucan rich composite flour biscuits: modelling of moisture sorption isotherms and determination of sorption heat. Journal of Food Science and Technology, 52(9), 5497-5509. http://dx.doi. org/10.1007/s13197-014-1658-2. PMid:26344964.

Pasha, I., Anjum, F. M., Butt, M. S., \& Sultan, J. I. J. (2007). Gluten quality prediction and correlation studies in spring wheats. Journal of Food Quality, 30(4), 438-449. http://dx.doi.org/10.1111/j.17454557.2007.00133.x.

Pasha, I., Butt, M., Anjum, F., \& Shehzadi, N. J. (2002). Effect of dietetic sweeteners on the quality of cookies. International Journal of Agriculture and Biology, 4(2), 245-248.

Pasha, I., Khan, Q. A. B., Butt, M. S., \& Saeed, M. J. (2013). Rheological and functional properties of pumpkin wheat composite flour. Pakistan Journal of Food Sciences, 23(2), 100-104.

Safdar, M. N., Siddiqui, N., Mumtaz, A., Amjad, M., Raza, S., \& Khan, Z. J. (2012). Comparison of new wheat varieties grown in Punjab for biscuit production. Sarhad Journal of Agriculture, 28(4), 647-654.

Šarić, B., Dapčević-Hadnađev, T., Hadnađev, M., Sakač, M., Mandić, A., Mišan, A., \& Škrobot, D. J. (2019). Fiber concentrates from raspberry and blueberry pomace in gluten-free cookie formulation: effect on dough rheology and cookie baking properties. Journal of Texture Studies, 50(2), 124-130. http://dx.doi.org/10.1111/jtxs.12374. PMid:30345519.

Shahzad, M. A., Ahmad, N., Ismail, T., Manzoor, M. F., Ismail, A., Ahmed, N., \& Akhtar, S. (2020). Nutritional composition and quality characterization of lotus (Nelumbo nucifera Gaertn.) seed flour supplemented cookies. Journal of Food Measurement and Characterization. In press. http://dx.doi.org/10.1007/s11694-02000622-x.

Sharif, K., Sadiq Butt, M., \& Huma, N. (2005). Oil extraction from rice industrial waste and its effect on physico-chemical characteristics of cookies. Nutrition \& Food Science, 35(6), 416-427. http://dx.doi. org/10.1108/00346650510633828.

Shubham, K., Anukiruthika, T., Dutta, S., Kashyap, A. V., Moses, J. A., \& Anandharamakrishnan, C. (2020). Iron deficiency anemia: a comprehensive review on iron absorption, bioavailability and emerging food fortification approaches. Trends in Food Science \& Technology, 99, 58-75. http://dx.doi.org/10.1016/j.tifs.2020.02.021.

Tagliani, C., Perez, C., Curutchet, A., Arcia, P., \& Cozzano, S. (2019). Blueberry pomace, valorization of an industry by-product source of fibre with antioxidant capacity. Food Science and Technology, 39(3), 644-651. http://dx.doi.org/10.1590/fst.00318.

Taylor, M., Kim, N., Smidt, G., Busby, C., McNally, S., Robinson, B., Kratz, S., \& Schnug, E. (2016). Trace element contaminants and radioactivity from phosphate fertiliser. In E. Schnug \& L. J. De Kok (Eds.), Phosphorus in agriculture: 100\% zero (pp. 231-266). Dordrecht: Springer. http://dx.doi.org/10.1007/978-94-017-7612-7_12.

Taylor, T., Fasina, O., \& Bell, L. J. (2008). Physical properties and consumer liking of cookies prepared by replacing sucrose with tagatose. Journal of Food Science, 73(3), S145-S151. http://dx.doi. org/10.1111/j.1750-3841.2007.00653.x. PMid:18387127.

Tyagi, P., Chauhan, A. K. J. L., \& Aparna. (2020). Optimization and characterization of functional cookies with addition of Tinospora cordifolia as a source of bioactive phenolic antioxidants. $L W T, 130$, 109639. http://dx.doi.org/10.1016/j.lwt.2020.109639.

Usman, M., Ahmed, S., Mehmood, A., Bilal, M., Patil, P. J., Akram, K., \& Farooq, U. (2020). Effect of apple pomace on nutrition, rheology of dough and cookies quality. Journal of Food Science and Technology, 57(9), 3244-3251. http://dx.doi.org/10.1007/s13197-020-04355-z. PMid:32728272.

Van den Briel, T., Cheung, E., Zewari, J., \& Khan, R. J. F. (2007). Fortifying food in the field to boost nutrition: case studies from Afghanistan, Angola, and Zambia. Food and Nutrition Bulletin, 28(3), 353-364. http://dx.doi.org/10.1177/156482650702800312. PMid:17974369.

Visioli, F., \& Hagen, T. M. J. P. (2007). Nutritional strategies for healthy cardiovascular aging: focus on micronutrients. Pharmacological Research, 55(3), 199-206. http://dx.doi.org/10.1016/j.phrs.2007.01.008. PMid:17317208.

Winger, R. J., König, J., \& House, D. A. (2008). Technological issues associated with iodine fortification of foods. Trends in Food Science \& Technology, 19(2), 94-101. http://dx.doi.org/10.1016/j.tifs.2007.08.002.

World Health Organization - WHO. (2000). The world health report 2000: health systems: improving performance. Geneva: WHO. 